Diagnosis-This is clinical. Radiographic changes are uncommon, and arthrography or magnetic resonance imaging is seldom indicated.

Management-Most patients recover spontaneously, and therefore reassurance and conservative measures are the main management. These include rest, jaw exercises (opening and closing), a soft diet, and analgesics. If these are insufficient, it can be helpful to use plastic splints on the occlusal surfaces (occlusal splints) to reduce joint loading, heat, ultrasound treatment, anxiolytic agents, or antidepressants. A very small minority of patients fail to respond to the above measures and require local corticosteroid or sclerosant therapy, local nerve destruction, or, often as a last resort, joint surgery.

Crispian Scully is dean and Rosemary Shotts is honorary lecturer at the Eastman Dental Institute for Oral Health Care Sciences, University College London, University of London (www.eastman.ucl.ac.uk).

The ABC of oral health is edited by Crispian Scully and will be published as a book in autumn 2000.

Crispian Scully is grateful for the advice of Rosemary Toy, general practitioner, Rickmansworth, Hertfordshire.

\section{Further reading}

- Krause I, Rosen Y, Kaplan I, Milo G, Guedj D, Molad Y, et al. Recurrent aphthous stomatitis in Behcet's disease: clinical features and correlation with systemic disease expression and severity.J Oral Pathol Med 1999;28:193-6

- Marbach JJ. Medically unexplained chronic orofacial pain. Temporomandibular pain and dysfunction syndrome, orofacial phantom pain, burning mouth syndrome, and trigeminal neuralgia. Med Clin North Am 1999;83:691-710, vi-vii

- Porter SR, Scully C, Pedersen A. Recurrent aphthous stomatitis. Crit Rev Oral Biol Med 1998;9:306-21

- Sakane T, Takeno M, Suzuki N, Inaba G. Behcet's disease. N EnglJ Med 1999;341;1284-91

- Scully C. A review of common mucocutaneous disorders affecting the mouth and lips. Ann Acad Med Singapore 1999;28:704-7

- Scully C, Flint S, Porter SR. Oral diseases. London: Martin Dunitz, 1996

- Tammiala-Salonen T, Forssell H. Trazodone in burning mouth pain: a placebo-controlled, double-blind study.J Orofac Pain 1999;13:83-8

- Van der Waal I. The burning mouth syndrome. Copenhagen: Munksgaard, 1990

\title{
A patient who changed my practice
}

\section{The internet and a "small miracle"}

I have just returned from a mother's day concert at my 6 year old's primary school. The first "welcome" statement was made by a friend of hers, $\mathrm{A}$, in a loud clear voice-a remarkable achievement for this particular child.

I have known A since she was a baby, watching her and two younger siblings pass through the baby clinic and reach normal development milestones. A was always a quiet child in company, but I was surprised to hear my daughter, in A's class at nursery, remark one day, "You know Mummy, A never speaks at school." There was no hint of developmental delay, and at home A interacted quite normally with her family. The transition to primary school saw a persistence of A's determined silence-no verbal interaction at all with her class mates or her teachers, although her basic literacy and numeracy skills developed in line with those of her peers.

A's parents were worried but remained patient and expectant-they at least knew her much more normal behaviour at home. By the beginning of her second year at school A had still not uttered a single word at school. She also refused to remove her shoes and socks for physical education in front of others and would eat nothing all day, neither school dinners nor a packed lunch. A's parents asked for a specialist review, wondering if any form of therapy would lead to more normal childhood interaction. No specific help resulted from this psychiatric assessment, but at least A now had a label "selective mutism," and in today's world a label by itself can begin to unlock doors.

I have to say my heart sank a little at the sight of sheets of internet printouts in A's mother's hand when she came in to see me a couple of weeks after the psychiatric clinic appointment. This was not because I resent patients accessing health information but because I don't know how to judge the quality or validity of this information-I don't know how to use it to make clinical decisions. But I was impressed. A series of case reports and parents' stories of children seemingly similar to A who had responded dramatically to short courses of fluoxetine.
This drug is not licensed for children in the United Kingdom, but our local drug information pharmacist was able to locate a small trial describing its use in children with selective mutism. ${ }^{1}$ A's parents and I talked about the concerns relating to the use of unlicensed medication, and I thought that I had to share my reservations explicitly, drawing up a clear contract acknowledging our shared responsibility in using this drug on their child.

Within two weeks of starting the drug, A was recording taped messages for her teacher and beginning to participate in physical education. After six weeks she is chattering happily with her friends at school and has been to her first party alone. She has been transformed into a totally "normal" 6 year old, and her parents are slowly withdrawing the fluoxetine.

I am convinced that the use of fluoxetine has played a central part in this huge change in A's behaviour, and I am equally sure that without the internet her parents could not have accessed this information. So if my heart sinks again at the sight of a patient's internet printout, I will simply remind myself of the small miracle of A and suspend my prejudgment.

Di Jelley general practitioner, North Shields

1 Dummit RS, Klein RG, Tancer NK, Asche B, Martin J. Fluoxetine treatment of children with selective mutism: an open trial. J Am Acad Child Adolesc Psychiatry 1966;35:615-21.

We welcome articles of up to 600 words on topics such as A memorable patient, A paper that changed my practice, My most unfortunate mistake, or any other piece conveying instruction, pathos, or humour. If possible the article should be supplied on a disk. Permission is needed from the patient or a relative if an identifiable patient is referred to. We also welcome contributions for "Endpieces," consisting of quotations of up to 80 words (but most are considerably shorter) from any source, ancient or modern, which have appealed to the reader. 